DISSERTAÇŌES DE MESTRADO

1991 


\section{ALCOVER NETO, Arnaldo}

Evolução supérgena das rochas carbonatíticas ricas em apatita do Complexo Alcalino de Juquiă, SP. 07 de outubro. 131p. 1 vol. Orientador: Maria Cristina Toledo-Groke.

Resumo: O Complexo Alcalino-carbonatítico de Juquiá está localizado nas proximidades das coordenadas geográficas $47^{\circ} 21^{\prime}$ de longitude oeste e $24^{\circ} 24^{\prime}$ de latitude sul (SE do Estado de São Paulo). Intrudiu no Cretáceo Inferior (133 Ma.) num embasamento regional pré-cambriano formado predominantemente por rochas gnáissicas e migmatíticas. Sobre o Complexo de Juquiá, assim como em várias outras localidades da região, houve formação de espessos mantos de intemperismo, evoluídos provavelmente a partir do Terciário Superior.

Este trabalho observou as feiçōes mais típicas da alteração supérgena do corpo carbonatítico de Juquiá (rico em apatita) sob os aspectos macro e microscópicos e também químicos.

As técnicas utilizadas foram basicamente difratometria de raios- $\mathrm{X}$, microscopias 6́ptica e eletrônica de varredura com analisador pontual, análise termodiferencial e espectroscopia infravermelho. Algumas dosagens de ETR também foram efetuadas pela técnica de ativação neutrônica.

Através dos dados obtidos confirmou-se a característica isalterítica do manto de alteraçäo desenvolvido sobre as rochas carbonatíticas de Juquiá, onde a grande quantidade de apatita primária residual condiciona a sustentação da estrutura original da rocha. Os carbonatos primários, predominantemente dolomíticos, são totalmente lixiviados durante a alteração do carbonatito e a porosidade gerada é parcialmente ocupada por produtos ferruginosos supérgenos (oxi-hidróxidos), ricos ou não em manganês, e também por recristalizações de apatita secundária.

Outros minerais secundários de menor importância quantitativa caracterizados nos poros da isalterita estudada foram: barita, fosfato rico em ETR e fosfato de alumínio rico em bário, tipo gorceixita.

Abstract: The Late Cretaceous Juquiá Alkaline-Carbonatite Complex (Southeastern São Paulo State, Brazil), as well as the Precambrian gneissic and migmatitic basement are covered by a thick veneer of weathered products, developed probably since the Late Tertiary.

This research emphasizes the most typical macro and microscopic weathering features of the apatite-rich carbonatite rock, using X-ray diffractometry, optical and scanning electronic microscopy, thermodifferential analysis and infrared absorption spectroscopy techniques. Some REE analysis were performed by neutron activation.

The data confirm the predominantly isalteritic weathering cover developed over the Juquiá carbonatites rocks with their original fabric preserved due to the great amount of residual primary apatite. The primary carbonates (mainly dolomitic) were completely leached during the weathering, and the resulting porosity is partially filled with ferruginous supergenic oxyhydrates (Mn-rich or not), as well as with secondary, recrystallized apatite.

Minor amounts of other secondary minerals filling the pores of the isalterite were identified as barite, REE-bearing phosphates and Ba-rich aluminium phosphates, like gorceixite.

\section{BARBOSA, Cátia Fernandes}

Caracterização biossedimentológica quantitativa do sistema estuário-manguezal da Baía de Guaratuba, PR. 10 de maio. 119p. 1 vol. Orientador: Kenitiro Suguio. 
Resumo: Foram analisadas 58 amostras de sedimento da superfície de fundo do estuário e 60 do manguezal da Baía de Guaratuba, localizada no litoral sul do Estado do Paraná.

As amostras do estuário permitiram a discriminação de quatro subambientes pela análise sedimentológica e cinco subambientes baseados na análise microfaunística (foraminifferos e tecamebas). A distribuição das assembléias microfaunísticas (composta basicamente por espécimes aglutinantes), em conjunto com as fácies sedimentares definidas, demonstram estar este ambiente em processo de intensa sedimentação. Extensos depósitos de planície arenosa intermaré e inframaré, aqui encontrados, podem caracterizar a última fase dentro de uma seqūencia regressiva. A amostragem no manguezal permitiu reconhecer trés biofácies, demonstrando haver uma correlação vertical entre os tipos de vegetação, a altitude e a microfauna analisada. A distribuição descrita para o alto manguezal pode seguramente permitir a reconstituição de antigos níveis marinhos com um erro aproximado de $\pm 12 \mathrm{~cm}$.

Abstract: 58 surface bottom sediment samples of the estuary and 60 mangrove sediment samples were collected from the Guaratuba estuary, located on the southern coastline of the Paraná State, southern Brazil, approx, area: $170 \mathrm{~km}^{2}$.

From a sedimentological point of view, the 58 estuary samples define four different environment types, while five different zones were defined from microfaunistic analysis (foraminifera and thecamoebians). The distribution of microfauna assemblages - basically agglutinated foraminifera, when considered with the defined sedimentary facies, show intense deposition $(0.6-1.6 \mathrm{~cm} / \mathrm{year})$. These processes are mainly characterized by wide sub- and intertidal sheet sand deposits, seemingly the last phase of a regressive sequence.

The mangrove sampling distinguishes a sequence of 3 biofacies, emphasizing a vertical correlation of vegetation, altitude and microfauna. The described distribution for high mangroves can safely place former sea levels with a $\pm 12 \mathrm{~cm}$ accuracy.

\section{CAVALCANTE, Itabaraci Nazareno}

Estudo hidrogeológico de terreno cristalino com manto de intemperismo - área piloto de Atibaia, SP. 19 de março. 133p. 1 vol. Orientador: Aldo da Cunha Rebouças.

Resumo: Este trabalho mostra a pesquisa hidrogeologica desenvolvida em terreno cristalino com manto de intemperismo, na área piloto de Atibaia a sudeste do Estado de São Paulo, tendo por objetivo caracterizar as condiçốes de ocorrência das águas subterrâneas, avaliar as obras de captação e propor metodologia de estudo hidrogeológico para este meio.

A metodologia de trabalho constou, basicamente, da pesquisa bibliográfica, interpretaçáo fotogeológica e geologia de campo com cadastro de 79 poços tubulares, 157 poços escavados e 12 fontes, com medidas de $\mathrm{pH}$, condutividade elétrica, nível estático, coleta de 19 amostras d'água para análises físicoquímicas e implantação de três piezômetros multiníveis.

A regiáo é composta predominantemente pelo Complexo Gnafssico-Migmatítico de Amparo $(55,5 \%)$, Maciços Graníticos de Socorro (23\%) e Atibaia (9\%), aluvióes $(7,8 \%)$ e coberturas coluvionares $(3,9 \%)$. Possui três fases de dobramentos $\left(F_{n+1}, F_{n+2}\right.$ e $\left.F_{n+3}\right)$ com sinformes e antiformes, e é bastante fraturada, com a principal falha seccionada a área de SW para NE constituindo o prolongamento da Falha de Extrema.

Foram definidas duas zonas aqüfferas: manto de intemperismo e meio fraturado. O manto de 
intemperismo recobre a área com espessuras predominando no intervalo de $20-40 \mathrm{~m}$, alcançando até 60 metros. O nível estático das cacimbas é de 0,4 a 9,0 metros $(81 \%)$, vazão média de $0,9 \mathrm{~m}^{3} / \mathrm{h}$ e capacidade especifica de $0,225\left(\mathrm{~m}^{3} / \mathrm{h}\right) / \mathrm{m}$.

Os poços tubulares possuem vazão predominantemente abaixo de $10 \mathrm{~m}^{3} / \mathrm{h}(90 \%)$ e a capacidade especifica média é de $6 \times 10^{-2}\left(\mathrm{~m}^{3} / \mathrm{h}\right) / \mathrm{m}$.

As águas dos poços escavados sảo bicarbonatadas cálcicas e as dos tubulares são mistas, passando para sodicas e calcicas.

No geral não existe critério técnico para locação, perfuração e completação dos poços. A não aplicação das normas é visivel em quase todos os casos, existindo negligência quanto aos poços desativados e abandonados, causando um risco potencial de poluição às águas subterrâneas.

Abstract: This paper resulted from hydrogeological investigation developed on crystalline terrain with weathering cover in the Atibaia area, southeastern São Paulo State. The goal was to determine occurrence conditions of ground-water, to evaluate capitation worles, and to propose a method of study for that hydrogeological environment.

The work started by bibliographic research, followed by photointerpretation and field geology. A catalog of 79 tubular wells, 157 excavated wells, and 12 springs was organized, including measurements of $\mathrm{pH}$, electric conductivity and static levels. Water samples were collected in 19 sources and had their physical-chemical quality analysed. Also three multilevel piezometers were implanted.

The region is mainly composed by the Amparo Gneissic-Migmatic Complex $(55,5 \%)$, and by the granites of Socorro (23\%) and Atibaia (9\%), alluvium (7,8\%), and colluvium. Three folding phases are present $\left(F_{n+1}, F_{n+2}\right.$ and $\left.F_{n+3}\right)$, showing synforms and antiforms. Fracturing is intensive, with the Extrema Fault cutting the area along SW-NE.

Two aquifer zones were defined: regolith and fractured rock. The first covers the rock with thicknesses ranging from 20 to $40 \mathrm{~m}$ and reaching a maximum of $60 \mathrm{~m}$. Static levels in dug wells vary from 0,4 to $9 \mathrm{~m}$, and yelds average $0,9 \mathrm{~m}^{3} / \mathrm{h}$, with specific capacity of $0,225\left(\mathrm{~m}^{3} / \mathrm{h}\right) / \mathrm{m}$.

$6 \times 10^{-2}\left(\mathrm{~m}^{3} / \mathrm{h}\right) / \mathrm{m}$.

Tubular wells show yelds dominantly under $10 \mathrm{~m}^{3} / \mathrm{h}(9,0 \%)$, with average specific capacity of

Waters from dug wells are calcic bicarbonatic, but in tubular wells are mixed, sodic or calcic.

In general there have not been technical criteria for location, drilling, and completion of wells. There is negligence with abandoned or desactivated capitations, posing a potential risk of pollution of ground-water.

\section{DANTAS, Agamenon Sergio Lucas}

Geologia da Faixa São Roque e intrusivas associadas na região entre São Paulo e Mairiporã, norte de São Paulo, SP. 220p. 1 vol. Orientador: Benjamim Bley de Brito Neves.

Resumo: O presente trabalho sintetiza os estudos geológicos em área de $730 \mathrm{~km}^{2}$ a norte da cidade de São Paulo, englobando terrenos pré-cambrianos polideformados de evolução polifásica e policíclica pertencentes à Faixa São Roque. O mapeamento geológico efetuado, na escala 1:50.000, individualizou exposiçōes de rochas supracrustais metamórficas de baixo a médio grau do Grupo São Roque e do seu embasamento, bem como diversos maciços granitóides intrusivos. Sedimentos cenozóicos da Bacia de São Paulo e coberturas holocênicas completam o cenário geológico da área. 
O Embasamento Pré-São Roque é representado pelo Complexo Gnáissico-Migmatítico de idade admitida como do Proteroz6ico Inferior a Arqueano, que inclui rochas ortognáissicas miloniticasblastomiloníticas, diatexitos e metatexitos da Unidade Inferior, além de micaxistos, gnaisses e quartzitos da Unidade Superior, em parte correlacionáveis aos Complexos Amparo e Grupo Itapira, respectivamente.

O Grupo Săo Roque, do Proterozóico Médio, 6 subdividido em duas unidades litoestratigraficas que se relacionam transicional e tectonicamente. A Unidade Inferior, correlacionável ao Grupo Serra de Itaberaba, ê formada por uma seqūência predominantemente metapelítica, na qual se inserem importantes níveis metavulcânicos básicos a intermediários, localmente ácidos, intercalaçöes de rochas calciossilicáticas, metapsefitos e metapsamitos impuros são os demais tipos litológicos presentes. A Unidade Superior, correlacionável à Formação Piragibu, inclui seqüência metarrítmica (filitos bandados, metarritmitos siltico-argilosos, metarenitos bandados e metarenitos subarcoseanos), preservados na porção norte da área.

O plutonismo granitóide é representado por corpos intrusivos na seqũência, que foram agrupados em distintas suites, em função do seu relacionamento temporal com a principal fase de deformação.

A Sufte Pré-Tectônica inclui pequenas intrusões simples, alongadas, bastante deformadas, de composição variável de granodioritos até quartzo sienitos, posicionadas em estreita associaçäo com zonas de cisalhamentos do norte da área. Correspondem aos maciģos de Barroca Funda, Francisco Morato, Vargem Grande, Mato Dentro, Pedra Vermelha e Vila dos Remédios, parautóctones a autóctones, mesozonais, com posicionamento síncrono ou tardio ao primeiro evento deformacional atuante na área.

As suítes sin a tarditectônicas englobam os maciços da Cantareira, Mairiporã e Taipas, intrudidos em pulsos magmáticos sucessivos, os dois primeiros zonados e com feiçōes de baloneamento. De natureza parautóctone, mesozonal, definem diversas fácies texturais-petrográficas, de composição principal granodiorftica a monzogranítica.

A Suite Pós-Tectônica inclui as intrusões simples e epizonais, de Morro de Perus, Juqueri e bossas turmaliniferas de Perus, correspondendo a termos mais evoluídos e estreitamente associados aos diferenciados tardios pegmatíticos-aplíticos.

As análises químicas efetuadas apontam para um quimismo toleítico de natureza oceânica para as rochas metavulcânicas básicas, sugerindo incipiente diferenciação de oeste para leste da área. Com relação ao magmatismo granitóide, o padrão geoquímico demonstra o quimismo cálcio-alcalino peraluminoso e fontes magmáticas crustais para os diversos corpos, admitindo-se contribuição mantélica restrita nos maciços da Cantareira, Mairiporã e Taipas. $\mathrm{O}$ padrão de evolução magmática admite $\mathrm{a}$ atuação de processos de diferenciação magmática, metassomatismo e assimilação, apontando, à exceção dos corpos pré-tectônicos, para o co-magmatismo das suítes.

O metamorfismo é plurifacial e polifásico, de gran baixo a médio nas supracrustais e médio a alto no embasamento, tendo sido identificadas quatro fases de dobramentos nas supracrustais, com correspondência no embasamento, o qual admite deformaçōes mais antigas. As duas primeiras fases são as mais importantes, com a segunda imprimindo o padrão regional verificado na área, enquanto as duas últimas são de fraca intensidade e pouca penetratividade.

O padrão deformacional da área é extremamente complicado pelo intenso cisalhamento recorrente no tempo, enfeixado em três grandes zonas de cisalhamento (Jundiuvira, Mairiporã e Mandaqui), onde coexistem feiçôes de deformação dúcteis e rúpteis.

O quadro de evolução tectônica da área é sugestivo da ocorrência de tafrogênese intracontinental nos primórdios do Proterozóico Médio, com implantação de bacia do tipo rift assimétrico 
sobre assoalho ensiálico, com restrita abertura oceânica. Segue-se a deposição de seqüência vulcanosedimentar, em águas relativamente profundas, $\mathrm{em}$ condiçōes de instabilidade tectônica e variaçṓes episódicas do nfvel do mar, atestada por influxos terrígenos variados e tentativas abortadas de instauração de condições plataformais. Os depósitos de plataforma têm pouca expressão na área, sugerindo condiçōes distais. A seqüência metarritmica da Unidade Superior, indicativa de águas rasas, encerra a deposição, possuindo feiçőes similares às dos sistemas deltaicos.

Os eventos metamórficos e deformacionais posteriores estão relacionados ao fechamento da bacia, com início por volta de $1.300 \mathrm{Ma}$, com pico, possivelmente associado a processos de colisão continental, entre 700 e $800 \mathrm{Ma}$. Os dados geocronológicos existentes sugerem para o magmatismo granit6ide tardi- e p6́s-colisional, idades em torno de 620-700 Ma. e $550-580 \mathrm{Ma}$, respectivamente.

Abstract: This work presents the results of a geological research encompassing $730 \mathrm{~km}^{2}$ of essentially precambrian terrains of complex evolution, attributed to the São Roque Belt, in a region situated northward São Paulo city. A geological map in a 1:50.000 scale was also produced, displaying bodies of supracrustal metamorphic rocks of low to medium grade of the São Roque Group, then basement, as well as several intrusive granitic bodies. Cenozoic sediments of the São Paulo Basin and alluvial deposits complete the geological frame of the studied area.

The São Roque Group basement is constituted by the Gneiss-Migmatitic Complex of Lower Proterozoic to Archean age, including orthogneiss, milonite-blastomilonite, diatexite and metatexite in its Lower Unit, and also micaschist, gneiss and quartzite in its Upper Unit, partly correlated to Amparo Complex and Itapira Group, respectively.

The São Roque Group, of Medium Proterozoic age, is divided in two lithostratigraphic units with transitional or tectonic limits. The Lower Unit, correlated to the Serra de Itaberaba Group, is constituted by a predominantly metapellitic sequence, comprising important basic to intermediate metavolcanic levels, locally of acidic character. Other metasediments and calcossillicatic rocks occur in interspersed levels. The Upper Unit, correlated to Piragibu Formation, includes a sequence of metarythmic rocks, such as layered phyllites, silty-clayey metasediments, layered metarenites and subarcosean metarenites. These rocks occur in the northern part of the studied area.

An intense plutonic activity of granitic character is recorded by intrusive bodies which have been emplaced in this previous sequence. They have been grouped in different suites, accordingly to their age, relative to the main phase of deformation $F_{2}$.

The Pre-Tectonic Suite includes simple, very deformed, elongated, small intrusions whose composition vary from granodiorite to quartz sienite, closely associated to the shear zones of the northern part of the studied area. They correspond to the mesozonal autochtonous and parauthoctonous bodies named Barroca Funda, Francisco Morato, Vargem Grande, Mato Dentro, Pedra Vermelha and Vila dos Remédios. These rocks represent a late event relatively to the first metamorphic phase of the studied area.

The sintectonic to latetectonic suites comprise the Cantareira, Mairiporã and Taipas bodies, intruded in successive magmatic episodes. The two first ones are zoned and also present features of ballooning. They have mesozonal parauthochtonous nature and define several petrographic and textural facies, mainly granodioritic to monzonitic, limited by zones of dominance.

The Post-Tectonic Suite includes the simple epizonal intrusions Morro de Perus, Juqueri and the turmaliniferous pluton Perus. It corresponds to more evolved rock-types, closely associated to late pegmatitic-aplitic varieties.

Chemical analises point towards a tholeiitic oceanic nature in the case of the basic 
metavolcanic rocks, thus suggesting an east-westward trend of differentiation for the studied area. As far as the granitic magmatism is concerned, the geochemical pattern indicates a peraluminous behavior with predominantly crustal magmatic sources for all the bodies, and a limited mantle contribution in the case of Cantareira, Mairiporã and Taipas bodies. The pattern of magmatic evolution does not exclude processes of magmatic differentiation, metassomatism and assimilation which indicate the suites to be comagmatic, the pretectonic bodies excepted.

The metamorphic pattern of the area presents several facies and phases, varying from low to medium grade for supracrustal rocks and medium to high for their basement, which may have undergone still older phases of deformation. The two first phases are the most important ones; the second phase has imprinted the regional pattern observable in the area while the two last ones have low intensity and are weakly penetrative.

The deformation pattern is extremely complex due to repeated shearing processes. This resulted in three shear zones, Jundiuvira, Mairiporã and Mandaqui, where brittle and ductile features occur together.

The tectonic evolution of the area suggests an episode of intracontinental taphrogenesis in the very beggining of Medium Proterozoic, when a rift basin developed in ensialic grounds, with little oceanic opening. The deposition of a volcanic-sedimentary sequence followed, in relatively deep water, under conditions of tectonic instability and sea-level variation, recorded by several types of continental deposits and also by several interrupted essays of development of platform conditions. Platform deposits are scarse, thus suggesting distal conditions of sedimentation. The metarythmic sequence of the Upper Unit, indicative of shallow water, with features similar to the deltaic systems ones, closes the event of deposition.

Further metamorphic and deformation events are related to the closing of the basin which began around 1,300 Ma ago and was most intense about 700 to $800 \mathrm{Ma}$ ago, possibly during a process of continental collision. Available geochronological data suggest ages of about 620 to $700 \mathrm{Ma}$ to late-collision granitic magmatism and 550 to $580 \mathrm{Ma}$ to post-collision granitic magmatism.

\section{FERNANDES, Amélia João}

O Complexo Embu no leste do Estado de Sáo Paulo: contribuiçăo ao conhecimento da litoestratigrafia e da evoluçāo estrutural e metamórfica. 09 de maio. 120p. 1 vol. Orientador: Mario Cesar Heredia de Figueiredo.

Resumo: O embasamento pré-cambriano que aflora na região leste do Estado de São Paulo, a sudeste da Bacia de Taubaté, foi estudado em escala de reconhecimento, através de perfis regionais. Foi dada ênfase ao reconhecimento de grandes unidades mapeáveis, bem como à cvolução estrutural e metamórfica.

Foram definidas para o Complexo Embu (cujas rochas predominam na área estudada) três unidades de metassupracrustais denominadas de Redenção da Serra, Rio Paraibuna e Rio Una. Gnaisses peraluminosos e ( \pm granada)-biotita-plagioclásio gnaisses predominam na Unidade Redenção da Serra, enquanto quartzitos e rochas calciossilicáticas são mais abundantes na Unidade Rio Paraibuna. A Unidade Rio Una constitui-se de xistos, quartzo-xistos e quartzitos intercalados ritmicamente.

O Complexo Embu foi afetado por 5 fases de deformação. O metamorfismo principal, possivelmente do Proterozóico Superior, relaciona-se às duas primeiras fases e situa-se no final do grau médio e início do grau forte (zona da sillimanita-muscovita à zona da sillimanita-feldspato potássico, com anatexia local). A Unidade Rio Una permanece no grau médio, nas zonas da granada, estaurolita e 
sillimanita. A segunda fase de deformaçăo gerou a foliação principal, em posição plano-axial a dobras recumbentes, e $\varepsilon$ frequientemente acompanhada por uma textura blastomilonítica com achatamento e estiramento mineral de direção NE. À terceira fase de deformação relacionam-se grandes dobras apertadas a fechadas e inversảo e, à quarta, dobras normais, abertas a fechadas. A quinta fase é tardia e transversal ao trend regional NE.

O Complexo Embu foi intrudido em periodos pré-metamórficos por rochas tonalíticas a graníticas de afinidade cálcio-alcalina; e, posteriormente, à foliaçäo principal, por maciços sin- a tarditectônicos constituídos de biotita granitos porfiriticos e muscovita-biotita granitos equigranulares. Estes foram posicionados, segundo dados isotópicos $\mathrm{Rb}-\mathrm{Sr}$, entre 700 e $570 \mathrm{Ma}$.

O Complexo Rio Capivari, aqui definido, é composto por gnaisses migmatiticos, de composição tonalítica a granítica, corresponde ao embasamento do Complexo Embu, e aflora em três núcleos. Há evidências de que o Complexo Rio Capivari sofreu metamorfismo (gerador de leucossomas trondhjemíticos) anterior e mais intenso que o metamorfismo principal do Complexo Embu. Dados geocronológicos ( $\mathrm{Sm}-\mathrm{Nd}, \mathrm{Rd}-\mathrm{Sr}, \mathrm{Pb}-\mathrm{Pb}$ ) sugerem uma idade arqueana ou do Proterozóico Inferior para o Complexo Rio Capivari, além de um evento metamórfico, gerador de leucossomas, do Proterozóico Médio.

Na porçăo oriente-meridional da região estudada, a sul do Maciço Granítico de Natividade, ocorre o Complexo Costeiro. Ele é composto predominantemente por ortognaisses blastomiloníticos. Dados isotópicos $\mathrm{Rb}$-Sr sugerem idades iguais ou mais baixas que $630 \mathrm{Ma}$. para estas rochas. Acredita-se que o Complexo Costeiro foi tectonicamente justaposto ao Complexo Embu no final do Proteroz6ico Superior, depois do desenvolvimento da foliação principal do segundo complexo.

As zonas de cisalhamento que recortam a área fornecem-lhe um padrão de compartimentação em blocos amendoados e, provavelmente, foram ativas desde períodos penecontemporâneos à terceira fase de deformação do Complexo Embu, até Épocas posteriores à quarta fase. As rochas metamórficas, que ocupam as porçōes internas das zonas de cisalhamento, foram submetidas a um retrometamorfismo de baixo grau, e intrudidas por corpos alongados de granit6ides blastomiloniticos.

Abstract: The Precambrian basement cropping out in the eastern part of the São Paulo State, south of the Taubaté Basin, was studied in a reconnaissance scale, by means of regional profiles. Emphasis was placed on the recognition of large mappable units, as well as on the structural and metamorphic evolutions of these rocks.

The metamorphosed supracrustal units which predominate in the area belong to Embu Complex, in this work divided into three major units, defined as Redenção da Serra, Rio Paraibuna and Rio Una. Peraluminous gneisses and (+garnet)-biotite-plagioclase gneisses predominate in the Redença da Serra Unit, while quartzites and calc-silicate rocks are more prominent in the Rio Paraibuna Unit. The Rio Una Unit consists of rhythmic schists, quartz-schists and quartzites.

Five phases of deformation affected the Embu Complex. The main metamorphic event is coeval to the first two phases of deformation (of Late Proterozoic age?) and attained to high grade metamorphism (sillimanite-muscovite to sillimanite-K feldspar zones, with local anatexis) in the Redenção da Serra and Rio Paraibuna units. The Rio Una Unit reached a lower metamorphic grade, represented by the garnet, staurolite and sillimanite zones. The main foliation is parallel to the axial plane of recumbent folds of the second phase of deformation, which often developed a blastomylonitic texture with NE-trending mineral flattening and stretching. Large tight overtuned folds are associated with the third phase of deformation, whereas open to close folds mark the fourth phase. A late, fifth phase, is transversal to the regional NE trend. 
Intrusive granitoid rocks include: (1) pre-metamorphism tonalitic-granitic rocks with calcalkaline affinities now converted into orthogneisses, so far undated, and (2) syn to late tectonic batholiths and minor plutons dominated by porphyritic biotite granitoids and equigranular muscovite-biotite granites, whose available $\mathrm{Rb}-\mathrm{Sr}$ isotope data range between $700-570 \mathrm{Ma}$.

A unit of migmatitic gneisses of tonalitic to granitic composition was recognized as basement of the Embu Complex, cropping out as three nuclei, and herein named Rio Capivari Complex. It shows evidence of a strong metamorphic event that is not recorded in the Embu Complex and produced trondhjemitic leucossomes. Available geochronological data ( $\mathrm{Rb}-\mathrm{Sr}, \mathrm{Pb}-\mathrm{Pb})$ point to an Archean (2950$2750 \mathrm{Ma}$ ) or Lower Proterozoic (2,500 a 2,300 Ma) age for the Complex, with some reworking in the Middle Proterozoic (1,500-1,300 Ma).

In the southeastern portion of the area, occurs the Costeiro Complex that is predominantly composed of blastomylonitic orthogneisses; $\mathrm{Rb}-\mathrm{Sr}$ isotope data from literature yield ages equal to or lower than $630 \mathrm{Ma}$. It is believed that the Costeiro Complex was tectonically juxtaposed to the Embu Complex at the end of Late Proterozoic, after the development of the main foliation of the latter complex.

The studied area is cut by a series of large shear zones that were probably active contemporaneously to the third and outlast the fourth phases of deformation of the Embu Complex. The metamorphic rocks engaged in these shear zones underwent a low-grade retrogressive metamorphism and were intruded by elongated bodies of blastomylonitic granitoids.

\section{HACHIRO, Jorge}

Litotipos, associaçōes faciológicas e sistemas deposicionais da Formaçāo Irati no Estado de Sāo Paulo. 29 de maio. 174p. 1 vol. Orientador: Armando Márcio Coimbra.

Resumo: Este trabalho tem por finalidade abordar a petrografia e faciologia da Formação Irati (P), Grupo Passa Dois, no Estado de São Paulo, através do estudo sistemático de sedimentos procedentes de afloramentos naturais, cortes de estradas, pedreiras e testemunhos de sondagens.

De acordo com a ordem de empilhamento observada em seçóes geológicas regionais, procedeu-se minuciosa descrição petrográfica acompanhada de identificação das estruturas sedimentares e eventuais macrofósseis. Nesta etapa foram importantes as informaçóes encontradas nos perfis litologicos e geofísicos de perfuraçōes que atravessaram a unidade.

A caracterização macroscópica e microscópica dos litotipos propiciou, em prinćpio, a separação em subunidades litoestratigráficas informais, correspondentes a conjuntos de sedimentos reunidos por afinidades de origem e seqüência de sedimentação.

Esta coluna litoestratigráfica informal, baseada em unidades geneticamente relacionadas, permitiu idealizar um modelo preliminar a partir do qual foi possível identificar sete associaçóes de fácies, discriminadas por atributos conferidos pelos processos sedimentares atuantes no sítio deposicional.

No contexto sedimentar pós-glacial da Bacia do Paraná, dominado por um episódio de transgressão de grande amplitude, foram registradas, nos sedimentos da base do Grupo Passa Dois, três ciclos transgressivo-regressivos, de menor ordem, subordinados ao evento principal. $\mathrm{O}$ exame acurado da variedade faciológica, resultante da interação entre repetidas oscilações eustáticas e mudanças climáticas, permite pressupor, no Permiano Superior da Bacia do Paraná, a existência de vasta área de plataforma coberta por um mar interno do tipo epicontinental. 
Abstract: This paper presents the results of a research made on the petrography and faciology of the Irati Formation (P), Passa Dois Group, in the São Paulo State. The sedimentary samples were taken from natural outcrops, road cuts, quarries and bore hole cores.

Taking into account the observed piling order of regional geologic sections, detailed petrographic descriptions were accompanied by the identification of sedimentary structures and macrofossils eventually found in outcrops. At this stage some important information were obtained from geophysical and lithological profiles of holes drilled through the unity.

As a result of the macro and microscopic characterization of lithotypes, several informal subunities were initially conceived. They included sediments connected by similar origin and piling sequence. Seven faciological assemblages were then identified in those informal genetic units. They can be differentiated from each other by attributes pertaining to the domain of the sedimentary processes which were active in the depositional environment.

During the extensive transgression episode which prevailed through the postglacial sedimentation of the Paraná Basin three subordinate transgressive-regressive cycles became imprinted in the basal sediments of the Passa Dois Group. The accurate examination of the faciological variety which resulted from repeated eustatic and climatic changes allows one to assume for the Late Permian of the Parana Basin the existence of a vast platform covered by an inland epicontinental sea.

\section{LIMA FILHO, Francisco Pinheiro}

Fácies e ambientes deposicionais da Formaçāo Piaut (Pensilvaniano), Bacia do Pamalba. 26 de setembro. 137 p. 1 vol. Orientador: Antonio Carlos Rocha Campos.

Resumo: O objetivo desta dissertação é contribuir para a caracterizaçäo e interpretação das fácies e ambientes de sedimentação da Formação Piaú, Pensilvaniano (Morrowano-Atokano), Bacia do Parnaiba, Nordeste do Brasil. Os dados obtidos através da análise de testemunhos de sondagens, registros geofísicos de poços, mapas de litofácies, mediçōes de paleocorrentes, do uso de técnicas de leitura de fácies e de petrografia sedimentar indicam que a Formação Piaú, unidade da parte inferior da seqüência pensilvaniana-permotriássica da Bacia do Parnafba, depositou-se sob condiçốes gerais áridas, configurando um extenso deserto interior, associado a uma bacia marinha evaporítica. Sistemas deposicionais típicos dos ambientes identificados incluem: élico (campos de dunas, zonas de interduna seca e úmida), lacustre (lagos efêmeros), fluvial (wadis e lobos de suspensão), que se alternam, em afloramentos da borda leste da bacia, com fácies características de sistema deltaico (frente deltaica e pró-delta). Em direçăo à parte interna da Bacia do Parnaiba, passam a predominar os depósitos marinhos evaporiticos, representados por seqüencias ciclicas de folhelho, carbonato e anidrita. No contexto deposicional e paleogeográfico acima, interpretam-se os calcários fossilfferos da parte superior da Formação Piauí (Mocambo, Contendas, Meruoca, Carimã, Vidalgo e Boa Esperança) como sedimentos de plataforma carbonática ou lagunar, em parte, pelo menos, retrabalhados por ondas de tempestade. As relaçōes espaciais entre os diferentes sistemas não são ainda completamente conhecidas. Na porçăo inferior da Formaçâo Piaú, nota-se a predominância de fácies élicas no sul; deltaicas no leste, e carbonáticas e evaporíticas no nordeste da Bacia do Parnaíba. Depósitos litorâneos e pelíticos de plataforma ocorrem no noroeste da bacia, passando, na sua porção central, a fácies evaporiticas. Do ponto de vista litoestratigráfico, são redefinidos os limites inferior e superior da Formação Piau, em subsuperficie. 


\begin{abstract}
The objective of this dissertation is to contribute to the characterization and interpretation of facies and environments of deposition of the Piaui Formation, Pennsylvanian (Morrowan-Atokan), Parnaiba Basin, Northeastern Brazil. Data obtained through the analysis of well cores, geophysical records, lithofacies maps, paleocurrents measurements and the use of facies-reading and sedimentary petrography techniques indicate that the Piaur Formation, in the lower part of the Pennsylvanian-Permian-Triassic sequence of the Parnaiba Basin, was deposited under widespread arid conditions, in an extensive interior desert associated with an evaporitic marine basin. Typical sedimentary systems of these environments identified are: aeolian (dune fields, wet and dry interdune zones), lacustrine (ephemeral lakes), fluviatile (wadis and suspension lobos), which alternate in outcrops along the eastern margin of the basin with facies characteristic of a deltaic system (delta front and prodelta). Toward the internal portion of the Parnaiba Basin, evaporitic marine deposits represented by cyclic sequences of shale, carbonate and anhydrite predominate. Within the above depositional paleogeographical context, the fossiliferous carbonates of the upper part of the Piaur Formation (Mocambo, Contendas, Meruoca, Carimã, Vidalgo e Boa Esperança) are interpreted as carbonate platform or lagunal deposits, at least partially reworked by storms. The spatial distribution of the different systems is not yet completely understood. In the lower part of the Piaur Formation, aeolian facies predominate to the south; deltaic to the east; carbonatic and evaporitic to the northeast and seashore facies to the northwest of the Parnaiba Basin. The latter pass towards the central portion, of the basin to dominantly evaporitic sediments. From the lithostratigraphic point of view the lower and upper boundaries of the Piaur Formation, in subsurface, are redefined.
\end{abstract}

\title{
LUCHESI, Ivanir
}

Evolução petrogenética e metalogenética da Serra da Boa Vista, Quadrilátero Ferrífero, MG. 23 de agosto. 209p. 1 vol. Orientador: Johann Hans Daniel Schorscher.

Resumo: A área mapeada está localizada a cerca de $15 \mathrm{~km}$ a sul do município de Santa Bárbara, Minas Gerais, na porção leste do Quadrilátero Ferrifero, especificamente na Folha Catas Altas. As três unidades litoestratigráficas que a compõem são: a seqüência de rochas metaultramáficas do Grupo Quebra Osso, ocupando a porção ocidental, em contato tectonizado com a seqūência de rochas metassedimentares da Serra da Boa Vista (porção central), que está em contato tectônico por falha de empurrão com as rochas do Complexo Gnáissico-Migmatítico, que ocupam a porção oriental. A Serra da Boa Vista, alvo principal deste trabalho, é composta de uma sequeência metassedimentar clástica e subordinadamente química, compreendendo cinco unidades principais, da base para o topo: 1) quartzitos, quartzo-mica-xistos e filonitos do contato; 2) metaconglomerado basal, lenticular e descontínuo; 3) unidade aurífera da Mina do Quebra Osso, composta de quartzo-mica-xistos com fuchsita, grafita e pirita abundante e BIF's a metacherts subordinados; 4) metaconglomerados E/W, com estratificação gradacional e 5) quartzitos Serra da Boa Vista, com quartzitos brancos e subordinadamente quartzo-mica-xistos. O modelo evolutivo proposto envolve dois ciclos sedimentares em bacia tectonicamente ativa, sendo o inferior de influência de fan aluvial incluindo as três primeiras unidades supra citadas; e segundo ciclo de influência de braided alluvium e planície costeira, composto pelas duas últimas unidades. No contexto geológico regional, envolvendo os Supergrupos Minas e Espinhaço, a Sequeência da Serra Boa Vista é interpretada como um fácies transicional. As paragêneses metamórficas observadas e comparação com o contexto regional indicam fácies metamórfico do grau xisto verde médio a superior. A estruturação é de uma sinforma com aba leste em posição invertida e aba oeste em posição normal, formando uma estrutura homoclinal orientada 
segundo aproximadamente $\mathrm{N} 20 \mathrm{~W} / 70 \mathrm{NE}$. As mineralizaçōes $\mathrm{em}$ ouro na área mapeada ocorrem em litotipos pertencentes ao Supergrupo Rio das Velhas e à Seqüência da Serra da Boa Vista. Estudos mineralógicos-petrográficos e geoquímicos-estatísticos apontam para mineralização na Seqüência da Serra da Boa Vista como originadas por diferentes processos: para a Mina do Ouebra Osso, predominam processos de precipitação química sinsedimentares a sindiagenéticas em ambiente redutor, com posterior remobilização metamórfica e fixação de ouro em óxidos hidratados de ferro; para os metaconglomerados a origem do ouro seria por deposição detrítica do tipo paleoplacer. Para as formaçōes ferrfferas do Subgrupo Rio das Velhas, a geoquímica e forma de ocorrência indicam depósitos strata-bound sendo, a nível interpretativo, considerados de origem singenética.

Abstract: The mapped area is located around $15 \mathrm{~km}$ south of Santa Barbara, MG, in the Eastern portion of the Iron Quadrangle. The three main lithostratigraphic units which compose the area are: the metaultramafic sequence of Quebra Osso Group in the western portion, in tectonized contact with the metasedimentary sequence of rocks of Serra da Boa Vista (in the center), which is in tectonic contact by thrust fault with the Gnaissic-Migmatitic Complex, which occupies the eastern portion. The Serra da Boa Vista, main aim of the present work, is composed of a metasedimentary clastic sequence, and secondly chemical, involving five main units, from base to top: 1) quartzites, quartz-mica-schists and filonites of the contact; 2) basal metaconglomerates, in lenses and descontinuous; 3) the gold-bearing unit of Quebra Osso mine, composed of quartz-mica-schists with fuchsite, graphite and abundant pyrite, and BIF to metachert in minor importance; 4) metaconglomerates $\mathrm{E} / \mathrm{W}$, with gradational stratification and 5) the Serra da Boa Vista quartzites, composed of white quartzites and secondly of quartz-mica-schists lenses. The proposed evolution model involves two sedimentary cycles in a tectonic active basin: the lower one of the alluvial-fan type, and the upper one of the braided alluvium type. In a broad geological context including the Minas and Espinhaço Supergroups, the Serra da Boa Vista Sequence is interpreted as a transitional facies. The metamorphic paragenesis observed compared to the regional context points to medium-to-superior greenschist metamorphic facies. The structure is sinformal type with the east limb inverted and the west limb normal, forming a homoclinal structure with strike of N20W and dipping 70NE. The gold mineralizations of the mapped area occur in linotypes of the Rio das Velhas Supergroup and of the Serra da Boa Vista sequence mineralogical-petrographical and geochemical statistical studies point to different processes generating the mineralizations in the Serra da Boa Vista Sequence: for the Quebra Osso mine predominates synsedimentary to syndiagenetic chemical precipitation process with later metamorphic remobilizations and fixation of gold through lateritic process; for the metaconglomerates, the origin of the gold would be due to detritical deposition of the paleoplacer type. For the Archean iron formations of the Rio das Velhas Supergroup, the geochemistry, and shape of the bodies point to strata-bound deposits being. on a interpretative level, considered of syngenetic filiation.

\section{MACHIAVELL, Adilson}

Os granitóides deformados da regiâo de Piên (PR): um provável arco magmático do Proterozóico Superior. 11 de novembro. 69p. 1 vol. Orientador: Miguel Angelo Stipp Basei.

Resumo: Localizada a aproximadamente $100 \mathrm{~km}$ a sul de Curitiba a área objeto deste trabalho apresenta dois domínios litologicos principais: um domínio meridional de rochas granulíticas e um domínio setentrional de rochas granitoides calcio-alcalinas deformadas. Além destes litotipos ocorrem ainda rochas 
ultrabásicas a básicas, um corpo granitoide isótropo e rochas vulcano-sedimentares da Bacia de Campo Alegre, sedimentares da Bacia do Paraná e depósito aluvionares recentes.

O domínio das rochas granuliticas está constituido essencialmente por gnaisses granulíticos quartzo-feldspáticos com ou sem hiperstênio, bandados ou listrados, englobando porçốes menores de piroxenitos e, mais raramente, anfibolitos.

O domínio dos granitoides cálcio-alcalinos deformados apresenta dois corpos principais, denominados informalmente de Granitos Sudeste e Noroeste, sendo que o primeiro está subdividido nas fácies 1 (hornblenda quartzo-monzodiorito a quartzo-monzonito) e 2 (biotita monzogranito a granodiorito) e o segundo nas fácies 3 (biotita-hornblenda quartzo monzodiorito a monzogranito) e 4 (biotita monzogranito).

O conjunto destes granitoides apresenta padrões geoquímico, geocronológico e petrográfico correspondente a granitóides originados em ambiente de arco vulcânico maturo e, de forma geral, apresentam claras evidências de metamorfismo de baixo grau (zona da biotita) associado a uma deformação cisalhante.

A feiçâo estrutural principal em todos estes corpos de granitoides é uma foliação gnáissica $\left(\mathrm{S}_{1}\right)$ mais ou menos desenvolvida, caracterizada pela orientação preferencial de quartzo, dos minerais máficos (biotita e/ou hornblenda) e dos feldspatos, notadamente quando componentes da matriz, e que apresenta como direção modal uma atitude de N43E/71NW.

A passagem entre estes dois domínios está marcada por uma zona de cisalhamento resultante do cavalgamento dos granitóides deformados sobre o domínio granulitico.

Os corpos ultrabásicos a básicos encontram-se, em geral, deformados e metamorfisados em grau baixo, constituindo-se predominantemente por serpentinitos, talco xistos, tremolita-talco xistos, com porçôes menores de anfibolitos, metagabronoritos, metaolivina gabronoritos e metanoritos. Estes corpos são encontrados quer em meio aos litotipos correspondentes ao domínio granulítico, quer em meio aos granitóides deformados, ou mesmo na zona de transição entre estes dois domínios, podendo representar, pelo menos em parte, restos de um fundo oceânico.

Um corpo granitóide isótropo, denominado de Granito Agudos, encontra-se intrudido no domínio granulítico, tendo como limite norte, na área representada pelo anexo 1, a mesma falha de cavalgamento que separa o domínio granulítico do domínio dos granitoides deformados.

Dentro deste corpo granítico ocorrem dois corpos básicos, gabro-dioríticos, de cores verdes, escuras a acinzentadas, granulometria média a fina, eventualmente grossa, podendo apresentar megacristais de piroxênios, anfibólios e plagioclásio, mostrando, geralmente, uma desestabilizaçăo, mais ou menos intensa, da mineralogia original da rocha - plagioclásio, piroxênio, olivina e anfibólio - em um processo essencialmente hidrotermal.

Geocronologicamente, o domínio granulítico apresenta neste trabalho, uma errócrona $\mathrm{Rb}-\mathrm{Sr}$

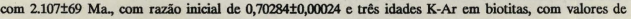
$1.910 \pm 47 \mathrm{Ma}$., $1.672 \pm 77 \mathrm{Ma}$. e $655 \pm 9 \mathrm{Ma}$, que indicam o metamorfismo e soerguimento destes litotipos no Ciclo Transamazônico, bem como a abertura do sistema K-Ar nas proximidades do contato deste domínio com os granitóides deformados, indicada pela idade de $655 \mathrm{Ma}$. em um biotita-piroxenito próximo a este contato.

Quanto ao domínio dos granitoides cálcio-alcalinos deformados, a metodologia $\mathrm{Rb}$-Sr forneceu, unindo-se os dados apresentados neste trabalho com dados ainda inéditos de J.M.REIS NETO e O.SIGA JR. duas retas paralelas com idades em torno de $610 \mathrm{Ma}$. e razões iniciais próximas de $0,705 \mathrm{c}$ 0,707, e pelo método U-Pb em zircōes, dados preliminares indicaram duas idades, $716 \pm 15 \mathrm{Ma}$. e $797 \pm 158$ 
Ma., sugestivas da geração destes granit6ides durante o Ciclo Brasiliano. Pela metodologia K-Ar em biotitas, obteve-se dois valores, um de $592 \pm 30 \mathrm{Ma}$. e outro de $561 \pm 15 \mathrm{Ma}$, que indicam, em contraste com o domínio granulítico, que o resfriamento regional nessa área deu-se ao final do Proterozóico Superior

Abstract: The Piên-São Bento do Sul (PR-SC) area shows two majors contrasted lithological domains separated by a thrust shear zone that carried the deformed granitoids domain from the northern part over the southern granulitic gneissic domain. Associated with these two regional terrains several basic to ultrabasic bodies and isotropic granitoid plutons may be found. The western part of the area is covered by the Paleozoic sedimentary sequences of the Paraná Basin.

The granulitic domain is composed by massif to banded (hypersthene) quartzofeldspathic gneissic rocks with enclaves of pyroxenites and amphibolites. By its turn, the granitoids domain comprises: amphibole bearing quartz monzodiorites to quartz monzonites; biotite monzogranite to granodiorite; biotite-amphibole quartz monzodiorite to monzogranite and a biotite monzogranite that show different shearing levels. The geochemical data for these granitoids points to a calc alkaline composition related to a mature volcanic arc origin.

The basic to ultrabasic rocks located in both domains were, like the granitoids, submitted to a regional low grade metamorphic episode. Serpentinites, talc schists and tremolite-talc schists are the most common rocks. Despite the absence of chemical data, these rocks are interpreted at least partially, as obducted ophiolitic slices representing roots of a previous ocean floor.

The geochronological data shows a $\mathrm{Rb}-\mathrm{Sr}$ errorchron of $2,107 \mathrm{Ma}$ for the granulite metamorphism. Late Proterozoic ages - $610 \mathrm{Ma}$. (metamorphism?) on whole-rock Rb-Sr isochron and $716 \pm 15$ and $797 \pm 158 \mathrm{Ma}$ (igneous emplacement?) in U-Pb zircon - were obtained for the granitoids in the northern domain.

The K-Ar data on biotites display to the granulitic domain ages of $1,910,1,670$ and $655 \mathrm{Ma}$, the last one the nearest of the granitoid domain. To this latter one, ages of 592 and $561 \mathrm{Ma}$ were obtained by the same methodology.

\section{MASSOL, Marcos}

Relaçăo entre o embasamento cristalino e os sedimentos basais do Subgrupo Itararé na regiāo de Sorocaba-Salto de Pinapora, SP. 11 de abril. 94p. 1 vol. Orientador: Setembrino Petri.

Resumo: Este trabalho tem por objetivo apresentar contribuição à estratigrafia e evolução ambiental da parte inferior do Subgrupo Itararé na região de Sorocaba.

Considerando-se a predominância de corpos rochosos em determinados níveis estratigráficos do Subgrupo Itararé, subdividiu-se o mesmo em quatro conjuntos litológicos, denominados, a partir da base, 1, 2, 3 e 4. Para tanto, foi de grande importância a elaboração de seções geológicas de superfície, bem como a obtenção de perfil detalhado de uma sondagem realizada para captação de água subterrânea.

O conjunto litológico 1 compreende essencialmente diamictitos de matriz arenosa, depositados $\mathrm{em}$ ambiente com influência glacial sobre o embasamento cristalino, no qual pode ser constatada superfície polida, com estrias para $\mathrm{N} 55^{\circ} \mathrm{W}$.

Sobrejacente ao conjunto litológico 1 e ao embasamento cristalino, situa-se uma seqũência de clásticos essencialmente finos, depositados em condiçōes subaquáticas, com influência marinha no topo.

Sobreposto aos conjuntos litologicos 1 e 2 e transgredindo em direção ao embasamento 
cristalino, encontra-se um pacote essencialmente arenoso, originado em planicies de lavagem, aluviais e fluviodeltaicas, denominado conjunto litologico 3, no qual assentam-se siltitos depositados, possivelmente, em planícies de inundaçâo, considerados conjunto litológico 4.

Dispostos irregularmente sobre os conjuntos 3 e 4 encontram-se diamictitos maciços, de origem glacial, representando o final da sedimentação do Subgrupo Itararé na área estudada.

Constatou-se no km 132 da rodovia SP-264, no extremo sul da área, a ocorrência de rocha metabásica (epidosito) pertencente ao Grupo São Roque, cuja superficie polida e estriada e sua morfologia, ainda que parcialmente recoberta por sedimentos, permitiram interpretá-la como moutonnée. As feições glaciais originaram-se da glaciação responsável pela deposição do conjunto litológico 1 , no Carbonffero.

A cerca de $180 \mathrm{~m}$ do contato do Subgrupo Itararé com o embasamento cristalino, no topo do conjunto litologico 2, afloram sedimentos contendo fosseis marinhos datados do Carbonifero Superior.

O estudo de paleotopografia do embasamento permitiu a constatação de elevações e depressōes que condicionaram a deposição dos sedimentos do Subgrupo Itararé, além de possibilitarem nova interpretação quanto à posição estratigráfica dos corpos rochosos ocorrentes na área. $\mathrm{O}$ conceito que se adotava até entāo admitia o empilhamento vertical dos litossomas a partir da borda da bacia para o interior. Na realidade, sedimentos da área estudada, localizados na margem leste da bacia, são de topo, recobrindo, por onlap, sedimentos mais antigos.

Abstract: It is presented herein a contribution to the stratigraphy and environmental evolution of the Permo-Carboniferous Itararé Subgroup sediments as developed in the Sorocaba region of the Paraná sedimentary basin, São Paulo State .

Some surface geological sections as well as the detailed geological description of a whole cored well drilled for underground water allowed the stratigraphical subdivision of the local PermoCarboniferous sediments into informal lithological unities numbered one (the lowest) to four (the upmost).

The unity one is essentially made up of arenaceous matrix diamictites thought to be derived through reworked glacial beds by water. It rests directly on the crystalline basement, which, in one place, is polished and bearing striate striking $\mathrm{N} 55^{\circ} \mathrm{W}$.

The unity two is essentially made up of fine clastics, mainly siltstones, througth to be laid down in subaqueous environments. Its uppermost beds bear marine fossils, Pennsylvanian palynomorphs, agglutinated Foraminifera and Orbiculoidea. These fossiliferous beds lay $180 \mathrm{~m}$ above the crystalline basement as present in the above mentioned well drilled for underground water. This unity rests either on beds of the unity one or directly on the crystalline basement.

The unity three is essentially arenaceous, resting on the unity two but overlapping it toward the border of the basin where it rests directly on the crystalline basement. This unity is thought to be generated in washing plains, alluvial and fluviodeltaic environments.

The unity four is essentially made up of siltstones laid down on the unity three and possibly generated in flood plains.

Diamictites and tillites are irregularly scattered either on unity three or unity four.

A roche moutonnée was recognized at $\mathrm{km} 132$ of the road Salto de Pirapora-Pilar do Sul (SP264). It is formed by Precambrian metabasic rock (epidosite) of the São Roque Group. Its polished and striated surface is covered by water reworked glacial beds grading upward to finer clastics. Is is interpreted as the result of the glacial advance, which generated the unity one.

Several wells drilled for underground water as well as electroresistivity geophysical profiles, allowed the recognition of a paleotopography of the basement of the Itarare Subgroup, specifically a 
paleovalley thought to be at least partially pre-Itararé eventually deformed by the Araçoiaba JurassicCretaceous alkaline intrusion.

The previous models of sedimentation in this region pointed to a piled up deposition of the lithosomes from the border so the border sediments would be the oldest ones. The model here proposed points to an onlap of the sediments toward the border so the eastern arenaceous sediments would be the youngest ones.

\section{MENEGASSE, Leila Nunes}

Estudo hidrogeologico das rochas metassedimentares do Grupo São Roque a NW da Grande São Paulo - critérios para locação de poşos profundos. 10 de outubro. 113p. 1 vol. Orientador: Uriel Duarte.

Resumo: O principal objetivo deste estudo é identificar a inter-relação entre os fatores litologicos e estruturais que interferem no comportamento do aquífero fraturado existente em uma área de $169 \mathrm{~km}^{2}$, situada a NW da região metropolitana da Grande São Paulo.

Todo o sistema páblico e industrial da região $€$ alimentada principalmente por poços profundos e, secundariamente, poços cacimba, de uso doméstico.

Geologicamente a área é representada por rochas metassedimentares de médio grau metamórfico, pertencentes ao Grupo São Roque, de idade do Proterozóico Superior, cortadas por corpos graníticos. Sucessivos eventos deformativos afetaram estas rochas, resultando em intensos dobramentos e fraturamentos.

A grande variação litologica e os intensos fraturamentos, aliados ao relativamente espesso manto de intemperismo, com 10 a $30 \mathrm{~m}$ em média, caracterizam os aquúferos da área.

Os dados de 51 poços profundos mostram que as principais entradas d'água ocorrem entre 50 e $100 \mathrm{~m}$. As produtividades são extremamente variáveis, com vazões entre 1,7 e $150 \mathrm{~m}^{3} / \mathrm{h}$ e capacidades especificas entre 0,02 e $66,7 \mathrm{~m}^{3} / \mathrm{hm}$. Cerca de $61 \%$ possuem vazões acima de $10 \mathrm{~m}^{3} / \mathrm{h}$, que é a média regional; $13 \%$ apresentam vazóes excepcionais, acima de $80 \mathrm{~m}^{3} / \mathrm{h}$, sendo que metade destes foram locados de acordo com estudos hidrogeológicos. Isto mostra a importância do uso de critérios hidrogeológicos para se obter sucesso na produção de poşos profundos.

Foi verificada a influência dos tipos litológicos e dos sistemas de lineamentos sobre a produtividade dos poços profundos, correlacionando estes condicionantes hidrogeológicos e os parâmetros hidráulicos vazâo e capacidade especifica.

Baseado nessas correlações, foi proposto um mapa de lineamento com indicação das zonas mais promissoras à perfuraçâo de poços profundos, correspondentes, principalmente, ao cruzamento dos sistemas longitudinal e transversal. Consta também neste mapa as áreas favoráveis à recarga, as quais estão normalmente cobertas por densa vegetação.

O grau de mineralização das águas amostradas é baixo, com valores de STD entre 30 e 118 $\mathrm{mg} / \mathrm{L}$. Os teores dos íons principais estão dentro dos limites de potabilidade, proporcionando águas de boa qualidade, nestes parâmetros.

O grande número de poços com boa produtividade, normalmente com vazóes acima de 10 $\mathrm{m}^{3} / \mathrm{h}$, denotam a alta potencialidade aqǘfera da área. Os fatores determinantes deste quadro são as excelentes condiçōes de recarga, resultantes do fator climático favorável, e da grande cobertura vegetal nas áreas de recarga, aliados à presença de denso fraturamento e de constante variação dos termos litológicos. 
Abstract: The main purpose of this work is to identify the interrelationship between lithological and structural factors which influence the behaviour of fractured aquifers existing in an area of 169 square kilometers in the northwestern part of the Metropolitan Region of Greater Săo Paulo.

The public and industrial water supply systems are obtained mainly from drilled deep-wells secondarily hand dug wells.

Geologically the area is represented by medium grade metasedimentary rocks cut by granitic bodies, belonging to the São Roque Group, of the Upper Proterozoic Age. Successive deformative events affected these rocks, resulting in intensive folding and fracturing patterns.

The wide variation of the lithology and intensive fracturing, allied to the thick weathering mantle, averaging between 10 to $30 \mathrm{~m}$, characterizes the aquifer zones. The principal water production zones are situated between the depth of 50 and $100 \mathrm{~m}$ below ground surface.

The data of 51 drilled deep-wells shows that the yields and specific capacities are extremely variable, with discharges ranging from 1,7 to $150 \mathrm{~m}^{3} / \mathrm{h}$ and specific capacities ranging from 0,02 to 66,7 $\mathrm{m}^{3} / \mathrm{h}$. About $61 \%$ of the wells have flow rates above $10 \mathrm{~m}^{3} / \mathrm{h}$, which is the regional average; $13 \%$ show exceptional high production, above $80 \mathrm{~m}^{3} / \mathrm{h}$, half of these have been located based on hydrogeologic studies. This demonstrate the importance of the use of hydrogeological techniques to obtain success in drilling deepwells in such geological conditions.

It was show, by correlating well, yields and specific capacities, with the hydrogeologic features, the influence of the lineaments and lithological types on the productivity of wells.

Based on these correlations a map was drawn showing the lineaments, the more favorable zones to drill deep-wells and the recharge areas, which are normally covered by dense vegetation.

The mineralization content of the sampled water is low, with TDS values ranging between 30 and $118 \mathrm{mg} / \mathrm{l}$. The major ionic contents are within the potability limits, providing good drinking water quality.

The great number of wells with good yields, normally above $10 \mathrm{~m}^{3} / \mathrm{h}$ in this area, reveals the high potentiality of the aquifer, due to the excellent climatic and recharge conditions, allied to the presence of fractures and lithologic contacts.

\section{OLIVEIRA, Nelson Marinho de}

Caracterização mineralógica e geoqufmica dos gossans portadores de ouro da região de São Bartolomeu, GO. 06 de dezembro. 123p. 1 vol. Orientador: Sonia Maria Barros de Oliveira.

Resumo: No presente trabalho utilizou-se de estudos petrográficos, geoquímicos e morfoscópicos para a caracterizaçẫo dos gossans auriferos constituintes do depósito de ouro de São Bartolomeu, GO.

O depósito de ouro de São Bartolomeu, situado dentro de uma zona de cisalhamento, é constituido por um pacote de filito hidrotermalizado com presença de vênulas e boudins de quartzo mineralizados, e por um conjunto de corpos sulfetados maciços ou parcialmente maciços, mais ou menos oxidados, alongados em forma de "charuto" e encaixados nos filitos do Grupo Canastra (proterozóico médio) segundo sua foliação principal.

O minério consiste de uma massa de oxi-hidróxidos de ferro secundários, impregnada de ouro. Estes 6xidos derivam da oxidação dos corpos de sulfetos maciços formadores da mineralização primária. Apresentam as texturas dos sulfetos quase inteiramente preservadas, e constituem gossans na acepcaáo clássica do termo. 
Os gossans são compostos por dois tipos de materiais misturados em várias proporçóes. O primeiro deles é o produto de alteração dos sulfetos e constitui-se de material ferruginoso; o segundo são restos do filito, com textura parcialmente conservada $\mathrm{e}$ fortemente ferruginizado.

A mineralogia é dominada por goethita, sericita e quartzo; hematita ocorre em quantidades subordinadas, assim como óxidos de ferro amorfos em variados graus de hidratação. Restos de sulfetos frescos e grãos de ouro de dimensão micrométrica que assumem formas esféricas, plac6ides ou dendríticas podem aparecer disseminados no plasma ferruginoso.

As texturas réplicas detectadas nos gossans são relacionadas às formas de ocorrência da pirita no minério primário. A principal forma de ocorrência da goethita é a cúbica, mas são muito freqũentes as formas retangulares e poligonais, além de ramificações dendriticas. Freqūentemente a goethita apresenta textura coloforme nos núcleos das cavidades dos baxworks ou margens de canais secundários.

Geoquimicamente os gossans são caracterizados pela assembléia: $\mathrm{Cu}-\mathrm{Pb}-\mathrm{Zn}-\mathrm{Au}-\mathrm{Ag}$. $\mathrm{A}$ análise dos coeficientes de correlação entre os elementos mostrou que o material é constituído por dois polos geoquímicos: o grupo de $\mathrm{SiO}_{2}$ e $\mathrm{Al}_{2} \mathrm{O}_{3}$ que tambem abrange o $\mathrm{B}, \mathrm{Ti}, \mathrm{V}, \mathrm{Y}, \mathrm{La}$, e Sc; e o grupo do $\mathrm{Fe}_{2} \mathrm{O}_{3}$ e pF que inclui o $\mathrm{Zn}, \mathrm{Pb}, \mathrm{Cu}$ e $\mathrm{Au}$. $\mathrm{FeO}$ e Ag não apresentam correlaçăo significativa com nenhum dos dois grupos. Esses grupos correspondem aos dois tipos de materiais que compõem as amostras.

A correlação do ouro com os demais elementos mostrou que da grande associação $\mathrm{Fe}_{2} \mathrm{O}_{3}$ PF-Cu-Pb-Zn-Au-Ag há duas subassociaçōes: $\mathrm{Fe}_{2} \mathrm{O}_{3}-\mathrm{PF}-\mathrm{Cu}-\mathrm{Pb}-\mathrm{Zn}$ e $\mathrm{Fe}_{2} \mathrm{O}_{3}$-PF-Au-Ag. O ouro, embora associado ao $\mathrm{Fe}_{2} \mathrm{O}_{3}$ nấo parece associado $\mathrm{ao} \mathrm{Cu}, \mathrm{Pb}$ e Zn.

As análises morfoscópicas das partículas de ouro indicaram haver ouro tanto de origem primária, quanto de origem secundária nos gossans, indicando a ação de algum enriquecimento supérgeno nas porções mais superficiais dos mesmos.

Abstract: In this present work different approaches are made utilizing petrographic, geochemical and morphoscopic studies for the characterization of gold gossans which form the gold deposits of São Bartolomeu, Goiás State, Brazil.

The São Bartolomeu gold deposit is situated in a shear zone made up of a sequence of hydrothermal phyllite with the presence of veinlets and boudins of quartz mineralized and also by massive or semi massive sulphide bodies, more on less oxidized and they are in the form of cigarette and are enclosed in the sequence of hydrothermal phyllite of Canastra Group following its principal foliation direction.

The ore is made up of a mass of oxyhydroxides of secondary iron impregnated with gold. These oxides are derived from the oxidation of bodies of massive sulphides forming the primary mineralization. They also possess textures of sulphides almost entirely well preserved and thus constitute gossan in the commonly accepted terminology.

The gossans are composed of two types of materials mixed in different proportions. The first one is the alteration product of sulphides and consists of ferruginous material; the second one is the rest of phyllite with texture partially conserved and highly ferruginous.

The mineralogy is dominated by goethite, sericite and quartz. Hematite occurs subordinately along with oxides of amorphous iron in different grades of hydration. Remains of fresh sulphides and grains of gold of micrometric dimensions have the shapes spherical, platy or dendritic may appear disseminated in the ferruginous plasma.

The replica textures observed in the gossans are related to the forms of primary pyrite occurrence. The principal shape of goethite is cubic and rectangular and polygonal forms, and dendritic ramification are also frequent. Commonly goethite represents colloform texture in the nucleus of cavities of boxworks or in the border of secondary channels. 
Geochemically the gossans are characterized by $\mathrm{Cu}-\mathrm{Pb}-\mathrm{Zn}-\mathrm{Au}-\mathrm{Ag}$ assembly. The correlation coefficient analysis shows that the material is made up of two geochemical poles. The first one consists of $\mathrm{SiO}_{2}, \mathrm{Al}_{2} \mathrm{O}_{3}$ and also includes $\mathrm{B}, \mathrm{Ti}, \mathrm{V}, \mathrm{Y}, \mathrm{La}$ e Sc; the second group is made up of $\mathrm{Fe}_{2} \mathrm{O}_{3}, \mathrm{PF}$ and includes $\mathrm{Zn}, \mathrm{Pb}, \mathrm{Cu}$ and $\mathrm{Au}$. $\mathrm{FeO}$ and $\mathrm{Ag}$ do not show any correlative relation with these two types. These two groups show a great deal of correspondence with two types materials of which they are made up of.

The correlation of gold with other elements demonstrate a greater association $\mathrm{Fe}_{2} \mathrm{O}_{3}-\mathrm{PF}-\mathrm{Cu}$ $\mathrm{Pb}-\mathrm{Zn}-\mathrm{Au}-\mathrm{Ag}$ consisting of two subassociations $\mathrm{Fe}_{2} \mathrm{O}_{3}-\mathrm{PF}-\mathrm{Cu}-\mathrm{Pb}-\mathrm{Zn}$ and $\mathrm{Fe}_{2} \mathrm{O}_{3}-\mathrm{PF}-\mathrm{Au}-\mathrm{Ag}$. The gold though associated with $\mathrm{Fe}_{2} \mathrm{O}_{3}$ does not appear associated with $\mathrm{Cu}-\mathrm{Pb}-\mathrm{Zn}$.

The morphoscopic analyses of gold particles show that the gold in the gossans can be of primary or secondary origin, indicating some action of supergene enrichment in the higher levels of the deposits.

\section{OLIVEIRA, Sandra de Fátima}

Acritarcas e prasinofitas da Formação Ponta Grossa (Devoniano) no flanco noroeste da Bacia do Paraná. 01 de julho. 227p. 1 vol. Orientador: Murilo Rodolfo de Lima.

Resumo: Esta dissertação é o resultado do estudo paleopalinológico (acritarcas s.L.) de 96 amostras provenientes da Formação Ponta Grossa ocorrentes no flanco noroeste da Bacia do Paraná. As amostras foram coletadas nas sondagens RSP-1 (Serra da Petrovina), RVR-1 (São José do Povo) e RPL-1 (Paraíso Leste), localizadas no sul do Estado do Mato Grosso, Brasil. Estas sondagens, de propriedade da Companhia Rio Doce Geologia e Mineraçăo S.A. - DOCEGEO, foram realizadas durante a execuçāo do Projeto Rondonópolis, em 1977.

Os sedimentos pertencentes à Formação Ponta Grossa revelaram-se portadores de uma rica e bem preservada assembléia de acritarcas s.L. Foram identificados 29 gêneros c 58 espécies, entre as quais são descritos 2 gêneros e 8 novas espécies: Bipolarisvelata accreta gen et sp.n., Mediocorpore conspicuus gen. et sp.n., Duvemaysphaera dissimilis sp.n., Duvernaysphaera heliocentrica sp.n., Evittia crucinata sp.n., Evittia matogrossensis sp.n., Gorgonisphaeridium reticulatum sp.n. e Pterospermella crassimanginata sp.n.

Com base na comparação entre a assembléia de acritarcas s.l. aqui analisada com outras descritas, até o momento, para diversas regiōes do mundo, alêm de estudos pré-existentes sobre esporos encontrados na área, foi possivel propor que a idade da seqūência sedimentar estudada corresponde ao intervalo de tempo situado entre o Eifeliano Inferior e Frasniano Superior.

Em relação ao paleoambiente, verificou-se a partir dos dados obtidos através da distribuição e diversidade dos microfósseis, que os sedimentos pertencentes à Formação Ponta Grossa, na área, foram depositados sob condiçôes marinhas, apresentando alguns intervalos, no entanto, influência continental.

Abstract: This dissertation is the result of a paleopalynologic study (acritarchs s.l.) of 96 samples from the Ponta Grossa Formation on the northwestern flank of Paraná Basin in Southern Mato Grosso State, Brazil. The samples were collected from boreholes RSP-1 (Serra da Petrovina), RVR-1 (São José do Povo) and RPL-1 (Paraíso Leste) drilled by the Companhia Rio Doce Geologia e Mineraçäo S.A. - DOCEGEO, during the Rondon6́polis Project in 1977.

The Ponta Grossa Formation possesses a rich and well-preserved acritarch assemblage. Twenty-nine genera and fifty-eight species were identified, among which two new genera and eight new species: Bipolarisvelata accreta gen. et sp.n., Mediocorpore conspicuo gen. et sp.n., Duvemaysphaera dissimilis 
sp.n., Duvemaysphaera heliocentrica sp.n., Evittia crucinata sp.n., Evittia matograssensis sp.n., Gorgonisphaeridium reticulatum sp.n. and Pterospermella crassimarginata sp.n.

Comparation with acritarchs described in the literature for other parts of the world and studies of spores from the same region suggest a Early Eifelian to Late Frasnian age for the studied sedimentary sequence.

The distribution and diversity of the microfossils in the Ponta Grossa Formation in the area indicate deposition under marine conditions, with continental influence in several intervals.

\section{PERROTTA, Mónica Mamzini}

A faixa Alto Rio Grande na regiāo a sul de São Gonçalo do Sapucat, MG. 07 de junho. 158p. 1 vol. Orientador: Benjamim Bley de Brito Neves.

Resumo: Situada na porção central da Faixa Alto Rio Grande, marginal ao Cráton do São Francisco, a área estudada compreende corpos tabulares ortognáissicos, que datam do Arqueano-Proterozóico Inferior, e faixas metassedimentares com evoluçâo no Proterozóico Médio.

No conjunto mais antigo, o Complexo São Gonçalo do Sapucaŕ, uma associação ortognáissicometavulcânica de gnaisses homogêneos e bandados, respectivamente, constitui na área a encaixante de corpos granitóides gnáissicos considerados como Complexo Amparo.

O conjunto metassedimentar, representado por pacotes de paragnaisses e associações rítmicas de xistos e quartzitos, tem continuidade física lateral com seqüências definidas a E-NE como Grupo Andrelândia.

Estes dois conjuntos estratigráficos, quando de evento deformacional principal, engajaram-se em nappes de dobramento, em posiçăo anticlinal, com estruturas sinclinais degeneradas e/ou com cavalgamentos ao longo dos flancos inversos. As unidades ortognáissicas constituem o núcleo de dobras cujo transporte foi para NNW.

Empilham-se na área, da base para o topo, as Nappes Rio Sapucai, Serra do Quiabeiro e Ribeirão do Cafundó (onde estabelecida a coluna estratigráfica local do Grupo Andrelândia). No topo desta pilha aloctone ocorre a Nappe de Cavalgamento Serra das Águas.

As estruturas em nappe evoluíram sob metamorfismo de grau médio, a pressões intermediárias, com apogeu na zona da silimanita. Desenvolvem uma foliação penetrativa, correspondendo à xistosidade $S_{2}$ no Grupo Andrelândia, que transpốes e recupera uma superficie reliquiar $\mathrm{S}_{1}$.

As nappes săo afetadas por dobramentos homoaxiais inclinados para NNW de terceira fase. Desenvolvem a foliação $S_{3}$, xistosidade evoluída sob condigöes da zona da biotita.

Uma quarta fase de dobramentos normais e descontínuos, homoaxial às anteriores, desenvolve nos metassedimentos uma clivagem de crenulação discreta ou, localmente, uma xistosidade fraca a biotita.

Faixas de cisalhamento subverticais cortam a área em continuidade com a Zona de Cisalhamento Três Corações a NE. Tem história evolucional complexa, iniciando-se precocemente à terceira fase de dobramentos e admitindo removimentaçōes posteriores às dobras de quarta fase.

Uma quinta fase de dobramentos ortogonais é responsável por amplas inflexões delineadas pelos contatos litologicos.

Abstract: The studied area, located in the central portion of the Alto Rio Grande Belt, at the border of 
the Francisco Craton, is made of tabular Archean-Early Proterozoic orthogneissic bodies and metasedimentary belts with Middle Proterozoic evolution.

In the older sequence, the Săo Gonçalo do Sapucar Complex, an orthogneissic-metavolcanic association of homogeneous and banded gneisses, respectively, is the country rock of the Amparo Complex gneissic granitoid bodies.

The metasedimentary sequence is represented by paragneisses and schist-quartzite rhythmic associations and is in the lateral continuity with sequences defined as the Andrelândia Group eastnortheastwards.

These two stratigraphic domains were involved, during the main deformational event, in anticlinal fold nappes with degenerated synclinal structures and/or with thrusting along the inverted limbs. The orthogneissic units constitute fold nuclei with north-northwestward transport.

From the base to top, the Rio Sapucaí, Serra do Quiabeiro and Ribeirão do Cafundó Nappes are piled up. The last one last one is where the local stratigraphic column of the Ándrelândia Group was established. The Serra das Águas Thrust Nappe occurs at the top of this allochthonous pile.

The nappe structures evolved under medium pressure-medium grade metamorphism reaching the sillimanite zone. They develop a penetrative foliation, corresponding to the $S_{2}$ schistosity of the Andrelândia Group, which transposes and recuperates a $S_{1}$ relict surface.

The nappes are affected by a third phase homoaxial folding, north-northwesterly inclined, and develops the $\mathrm{S}_{3}$ foliation, a schistosity developing under biotite zone conditions.

A fourth phase normal and discontinuous folding, homoaxial to the previous ones, develop in the metasediments a discreet crenulation cleavage or, locally, a biotite-bearing weak schistosity.

Subvertical shear belts cut the area in continuity with the Três Coraçóes Fault northeastwards. They have a complex evolutionary history starting before the third fold phase and still continuing until after the folds of the fourth phase.

A fifth folding phase, orthogonal to the earlier ones, is responsible for the large inflections delineated by the lithological contacts.

\section{PRESSINOTTI, Márcia Maria Nogueira}

Caracterizaçāo geológica e aspectos genéticos dos depósitos de aryilas tipo "ball clay" de Sāo Simäo, SP. 02 de julho. 141p. 1 vol. Orientador: Adolpho José Melfi.

Resumo: As argilas tipo ball clay de São Simão são conhecidas por sua elevada plasticidade e resistência mecânica, propriedades estas específicas para a indústria de cerâmica branca, na qual atingem significativo valor comercial. Ocorrem em lentes e camadas irregulares associadas aos depósitos aluvionares quaternários, do Ribeirão Tamanduá, que se localiza a oeste da cidade de São Simão, SP.

Os estudos realizados tiveram por finalidade caracterizar os processos geológicos e geoquímicos associados à gênese dessas argilas. Desta forma, o mapeamento geológico, a caracterização dos processos evolutivos neocenozoicos, ligados à alteração das áreas fontes dos depósitos aluvionares e a caracterizaçâo química e mineralógica das argilas, foram necessários a este propósito.

Estas argilas são de origem principalmente detrítica, formadas por deposição em planícies de inundação cujas fontes foram, predominantemente, os arenitos subarcosianos alterados das formaçōes mesozbicas arenosas e, secundariamente, as rochas básicas da Formação Serra Geral.

São caracterizadas por altos teores de caulinitas e menores quantidades de quartzo e micas. A 
matéria orgânica é muito freqüente nessas argilas e, possivelmente, responsável por grande parte de suas propriedades tecnologicas.

As caulinitas caracterizam-se por placas hexagonais de boa cristalinidade (com $1 \mu \mathrm{m}$ de diâmetro) ao lado de pequenas partículas irregulares com baixa cristalinidade (com diâmetros menores que $0,2 \mu \mathrm{m})$.

Análises químicas mostraram que as argilas possuem teores em cátions alcalinos e ferro extremamente baixos, e se encontram em um meio ácido e dessaturado.

Dataçōes radiométricas mostraram que esses depósitos são relativamente recentes, formandose no intervalo de tempo correspondente a, pelo menos, os últimos 33.000 anos BP, ou seja, no final do Pleistoceno ao Holoceno.

As argilas de São Simão, com base nas caracteristicas composicionais (químicas e mineralogicas), nâo poderiam ser classificadas como ball clay. Entretanto suas propriedades tectonológicas são similares às ball clays inglesas e americanas, o que justifica denominá-las de argilas tipo ball clay.

Abstract: The ball clays from São Simão are known by their high plasticity and mechanical strength properties, especially indicated for white ceramic manufacturing, having therefore, high commercial value.

These clays occur as irregular beds or lenses associated with quaternary alluvial deposits from Tamanduá River, west of São Simão town, São Paulo State.

The studies were carried out to determine the geological and geochemical processes that originated the ball clays. To understand these processes the geological mapping with attention to Late Cenozoic weathering of source areas of alluvial deposits, were undertaken and chemical and mineralogical characteristics were studied.

The origin of these clays is mainly detritical, through deposition on flood plains. The sources were predominantly weathered subarkose wackes from sandy mesozoic formations and secondarily from basic rocks of Early Cretaceous Serra Geral Formation.

Kaolinites are the predominant mineral of the clays, besides low contents of quartz and mica. The frequent organic matter is thought to be responsible for its technological properties.

The kaolinites are characterized by well-crystallized hexagonal flakes ( $1 \mu \mathrm{m}$ diameter) associated with small low degree crystallinity particles (diameters lesser than $0,2 \mu \mathrm{m}$ ).

The chemical analyses indicate that the clays have low contents of alkaline cations and iron, in acid and unsaturated conditions.

According to radiometric datings these deposits were originated at least 33,000 years B.P., in the Latest Pleistocene to Holocene.

The chemical and mineralogical composition of the São Simão clay does not correspond to the typical ball clay. Notwithstanding it may be considered a ball clay type inasmuch as it bears the same technological properties of English and North American ball clays.

\section{TAKIYA, Harmi}

Aplicação de métodos quantitativos espaciais a dados geológicos da Bacia de São Paulo. 22 de abril. 109p. 1 vol. Orientador: Paulo Miltom Barbosa Landim.

Resumo: Métodos geoestatísticos (semivariograma e krigeagem) e clássicos (inverso do quadrado da distância - L.Q.D.) foram utilizados no tratamento de 805 dados selecionados a partir de 3197 boletins de 
sondagens, pertencentes ao Departamento de Águas e Energia Elétrica - DAEE e à Companhia do Metropolitano do São Paulo - METRÓ.

A região estudada corresponde à porção centro-oeste da Bacia de São Paulo, mais precisamente localizada entre as coordenadas (UTM) 320 a $350 \mathrm{~km}$ (E) e 7380 a $7410 \mathrm{~km}$ (N).

São aqui apresentados mapas de contorno estrutural, iśbacas, isరlitas e porcentagem dos sedimentos terciários da Bacia de São Paulo, além de um mapa geológico, todos em escala 1:100.000.

A partir das informaçōes já existentes sobre a área e da análise dos mapas e perfis elaborados pôde-se reconhecer cinco unidades, delimitadas no mapa geológico, conforme seguem:

- Formação Resende (Tf): constituída predominantemente por depositos rudáceos proximais (Tff) e lamíticos distais (Tfl) de sistemas de leques aluviais. Na borda norte da bacia, sua espessura ultrapassa $200 \mathrm{~m}$;

- Depositos correlacionáveis à Formação Tremembé (TI): formados por sedimentos argilosiltosos lacustres, com espessuras de até $60 \mathrm{~m}$, encontrados sob os aluviōes atuais do Rio Tietê, na região da Barra Funda;

- Formação São Paulo (Tm): apresentando freqũentemente depósitos areno-silto-argilosos, e, secundariamente, conglomerados, relacionados a fluvial meandrante, atingindo espessuras que ultrapassam uma centena de metros;

- Formaçăo Itaquaquecetuba (Te), constituída em maior proporção por sedimentos arenoconglomeráticos de até $130 \mathrm{~m}$ de espessura, que ocorrem sob os aluviōes dos Rios Pinheiros e Tietê;

- Coberturas colúvio-aluviais quaternárias (Q): representadas por sedimentos argilo-arenoconglomeráticos, em geral com até 10 metros de espessura.

Atribui-se idade paleogênica às formaçōes Resende e São Paulo e aos depósitos correlacionáveis à Formação Tremembé. Diversas evidências apontam para a hipótese da Formação Itaquaquecetuba ser mais jovem do que as unidades mencionadas, embora, ainda não conclusiva.

Os mapas de contorno estrutural do topo do embasamento mostram possíveis compartimentações tectônicas na área estudada, definindo quatro blocos com aumento de cotas médias de Norte para Sul, atingindo de 650 ate $709 \mathrm{~m}$, o que evidencia basculamento de blocos para noroeste.

Os mapas de isópacas indicam maiores espessuras de sedimentos (mais de $200 \mathrm{~m}$ ) para a borda norte da bacia (próximo a Guarulhos) e na região leste (Moóca, Tatuapé, Vila Formosa), em concordância com as áreas de menores cotas do topo do embasamento, conforme verificadas no mapa de contorno estrutural.

Com o auxilio do mapa de porcentagem de argila delimitaram-se os depósitos correlacionáveis à Formação Tremembé, evidenciando a presença de um paleolago de aproximadamente $2 \mathrm{~km}^{2}$. Os mapas de porcentagem de areia, isópacas e de isolitas de argila foram fundamentais na determinação da ocorrência dos sedimentos da Formação Itaquaquecetuba.

Em termos da paleogeografia da Bacia de São Paulo, verificou-se que as paleodrenagens exibem boa coincidência com as feiçōes geomorfológicas atualmente observadas, principalmente, com relação aos aluviōes dos Rios Tamanduaté e Pinheiros.

Abstract: Geostatistical (semivariogram and kriging) and classic (inverse square-root distance) methods were used to analyse data from 805 wells selected from 3,197 borehole descriptions prepared by the Departmento de Águas e Energia Elétrica - DAEE and the Companhia do Metropolitano de São Paulo METRÔ for the central-western portion of the São Paulo Basin, Brazil.

Isopach, isolith and conglomerate, sand and clay percentage maps of the Tertiary sediments, 
together with structural contour maps and a geological map at a 1:100,000 scale, are presented. From previously available information and the analysis of the maps and cross-sections elaborated in this work, five lithostratigraphic units were recognized and delimited on the geological map, as follows:

- Resende Formation (Tf), consisting of proximal rudaceous (Tff) and distal mudstone (Tfi) deposits of alluvial fan systems, which can exceed $200 \mathrm{~m}$ in thickness on the northern border of the basin;

- Deposits correlatable with the Tremembe Formation (TI), comprising lacustrine silty-clayey sediments, up to $60 \mathrm{~m}$ thick, present below quaternary alluvial deposits of the Tietê River, in the Barra Funda neighborhood;

- São Paulo Formation (Tm), with clayed-silty-sandy deposits and subordinate conglomerates, related to a meandering fluvial system, with thicknesses exceeding $100 \mathrm{~m}$;

- Itaquaquecetuba Formation (Te), largely conglomeratic-sandy sediments, up to $130 \mathrm{~m}$ thick, underlying the present alluvial deposits of the Pinheiros and Tietê rivers;

- Quaternary colluvial-alluvial cover (Q), represented by conglomeratic-sandy-clayed sediments, usually up to 10 meters thick.

A Paleogene age is attributed to the Resende and São Paulo Formations and to the deposits correlatable with the Tremembe Formation. Although not conclusive, different evidence supports the hypothesis that the Itaquaquecetuba Formation is younger than the other units.

The structural contour maps of the top of the basement show possible tectonic compartments in the studied area, defined by four blocks with average altitude that increasing from $650 \mathrm{~m}$ in the north to $709 \mathrm{~m}$ in the south, which seems to corroborate a regional northwest tilting previously suggested by other authors.

The isopach maps indicate greater sediment thicknesses (more than $200 \mathrm{~m}$ ) toward the northern border of the basin (around Guarulhos) and in the eastern region (Mobca, Tatuape, Vila Formosa), in agreement with the lower altitude of the top of the basement, as verified on the structural contour map.

The deposits correlatable with the Tremembe Formation were delimited by means of the clay percentage map, which revealed the presence of a paleolake with approximately $2 \mathrm{~km}^{2}$ in area. The sand percentage, isopach and clay isolith maps were fundamental in determining the presence of the Itaquaquecetuba Formation.

The paleodrainage pattern of the São Paulo Basin shows a close relationship with present geomorphologic features, especially with respect to the alluvial deposits of the Tamanduatei and Pinheiros rivers.

\section{TRESSOLDI, Marilda}

Uma contribuiçāo à caracterizaçāo de maciços rochosos fraturados visando a proposiçāo de modelos para fins hidrogeologicos e hidrogeotécnicos. 21 de novembro. 382p. 1 vol. Orientador: Aldo da Cunha Rebouças.

Resumo: Fundamentando-se na consolidação das tendências atuais sobre a caracterização hidrogeologica e hidrogeotécnica de maciços rochosos fraturados (capítulo 2), é discutida a caracterização hidrogeologica e hidrogeotécnica efetuada em basaltos fraturados de Porto Primavera (capítulo 3), são apresentados exemplos de análises de fluxo em microcomputadores (capítulo 4), e são propostas algumas diretrizes gerais para a elaboração de modelos conceituais necessários às análises de fluxo (capítulo 5). 
Para caracterizar as propriedades hidrogeológicas e hidrogeotécnicas de um espesso pacote de basalto fraturado presente nas fundaçóes da barragem de terra da usina de Porto Primavera, visando a proposição de modelos para fins de análise de percolação, foi efetuado um programa de ensaios pioneiro na história das investigaçôes de fundaçōes das barragens brasileiras.

As investigações constaram de ensaios de intercomunicaçăo tridimensionais por bombeamento, precedidos de ensaios pontuais para uma primeira avaliação das condutividades hidráulicas. Os resultados indicaram que o maciço rochoso comporta-se como meio homogêneo e anisotrópico, sendo definidos os tensores bi e tridimensionais de condutividades hidráulicas, seus valores e direçóes principais e os valores de coeficientes de armazenamento específico, utilizando a solução de HSIEH et al. (1983), HSIEH \& NEUMAN (1985) e HSIEH et al. (1985).

Os ensaios e as interpretaçōes foram conduzidos em diversas dimensōes entre $5 \mathrm{~m}$ e $40 \mathrm{~m}$, evidenciaram a influência das dimensões nos resultados obtidos e mostraram correlaçôes com a geologia e com as estruturas do maciço basáltico, especialmente com os contatos entre derrames.

As análises de fluxo efetuadas em microcomputadores utilizaram o programa de análise de fluxo tridimensional MODFLOW (MACDONALD \& HARBAUGH, 1988) e trataram de casos idealizados referentes ao rebaixamento de uma mina em um maciço rochoso mineralizado e à influência de uma cortina de injeção atravessando basaltos fraturados. Essas análises ilustraram a utilização dos tensores tridimensionais de condutividades hidráulicas, especialmente dos seus valores e direções principais, bem como dos valores de coeficientes de armazenamento especifico, determinados através de ensaios in situ.

As diretrizes gerais para a proposição de modelos conceituais foram abordadas com ênfase à execução de ensaios in situ e ao emprego de métodos e técnicas estatísticas e geoestatísticas.

Abstract: Based on the consolidation of today's tendency on the hydrogeological and hydrogeotechnical characterization of fractured rock mass (chapter 2), the hydrogeological and hydrogeotechnical characterization carried out in fractured basalts in Porto Primavera is discussed (chapter 3), examples of seepage analyses in microcomputers are shown (chapter 4), and some general rules for the elaboration of conceptual models for seepage analyses are proposed (chapter 5).

To characterize the hydrogeological and hydrogeotechnical properties of a thick layer of fractured basalt present in the Porto Primavera hydroelectric powerplant earth dam foundation, aiming the proposition of models with the purpose of seepage analyses, a pioneer program of tests for dam foundation investigations was carried out.

The investigations consisted of tests of three-dimensional intercommunication through pumping, preceded by single-hole tests for a first evaluation of the hydraulic conductivity. The results have shown that the basaltic rock mass behaves as a homogeneous and anisotropic medium, having defined the tensors of bi and three-dimensional hydraulic conductivity, it's principal values and directions and the values of specific storage, using the HSIEH et al. (1983), HSIEH \& NEUMAN (1985) and HSIEH et al. (1985) solution.

The tests and interpretations were conducted in different scales between $5 \mathrm{~m}$ and $40 \mathrm{~m}$, the scale effects in the results were evidenced and the correlations with the geology and with the structures of the basaltic rock mass, mainly with the contacts between lava flows were shown.

Seepage analyses made in microcomputers used the program of three-dimensional flux MODFLOW (MACDONALD \& HARBAUGH, 1988) and dealt with cases that were idealized, related to the lowering of a mine in a mineralized rocks mass and to the influence of an injection curtain going through fractured basalts. These analyses illustrate the use of three-dimensional hydraulic conductivity tensors, 
mainly of its principal direction and values, as well as the values of specific storage, established by in-situ tests.

The general rules for the proposition of conceptual models were approached with emphasis to the execution of in-situ tests, and to the use of geastatistics and statistics techniques.

\section{VASCONCELLOS, Eleonora Maria Gouvêa}

Investigaçōes geológicas e petrológicas das brechas vulcânicas do Maciço de Tunas, SP. 18 de abril. 128p. 1 vol. Orientador: Celso de Barros Gomes.

Resumo: As brechas vulcânicas do Maciço Alcalino de Tunas são estudadas detalhadamente com base na sua petrografia e análise de minerais da matriz por microssonda.

O maciço é formado de sienitos, sienitos alcalinos, gabros, monzogabros, dioritos, monzodioritos, veios pegmatoides e diques alcalinos (traquitos, microssienitos e bostonitos). Essas rochas consistem de feldspatos, clinopiroxênios, biotitas e anfibolios em maior quantidade e, subordinadamente, de olivina, feldspat6ides ou quartzo, opacos, zircâo e apatita.

São descritos sete corpos de brechas aflorando em localidades diferentes do maciço, quatro na sua porção noroeste e três na parte central.

As brechas, classificadas como intrusivas de contudo e tufisíticas, sâo constituídas por clastos de rochas formadoras do maciço, rochas encaixantes e por fragmentos essenciais. Elas são também separadas com base no tipo de matriz.

O cálculo da proporção dos clastos em relação à matriz para fins de classificação textural, efetuado em diversas etapas, permite distinguir brechas suportadas por matriz, por matriz e clastos e somente por clastos (tipo menos comum).

Análises de feldspatos e piroxênios por microssonda revelam a estreita associação dessas rochas com as demais litologias alcalinas do maciço.

O modo de ocorrência, o tamanho, a forma e a composição dos clastos e o tipo de matriz das brechas de Tunas são comparados com dados de literatura. Para a sua formação propõe-se uma origem com base nos processos da fluidização, com participação de correntes fluidizadas.

Abstract: The volcanic breccias of the Tunas alkali massif are studied in details through their petrography and analysis of the matrix minerals by microprobe.

The massif is formed by syenites, alkali syenites, pegmatoids veins and alkali dikes (trachytes, microsyenites and bostonites). These rocks are fundamentally composed of feldspars, clinopyroxenes, biotites and amphiboles and, subordinately, of olivines, feldspatoids or quartz, opaques, zircon and apatite.

Seven breccia bodies are described in different outcrops of the massif, four bodies in the northwest portion and three bodies in the central portion.

The breccias are classified as intrusives of conduit and "tufisiticas". They are constituted of clasts of rocks that form the massif of country rocks and of essential fragments. These rocks are also classified by the kind of matrix.

The proportional balance of the clasts about the matrix (based on textural classification) permits the distinction of the breccias as: "matrix-supported", "clast-matrix-supported" and "clast-supported".

The microprobe analysis of feldspars and pyroxenes shows the association of these rocks with the other alkali lithology of the massif. 
The kind of matrix, the size, the form, the composition and how the clasts appear are compared with information from literature.

We propose (for its formation) a fluidization process with fluidity currents. 